\title{
Farmer participation in selection within segregating populations of cowpea in Volta Region, Ghana
}

\author{
Kenneth Fafa Egbadzor ${ }^{1,2^{*}}$, Samuel Kwame Offei ${ }^{5}$, Eric Yirenkyi Danquah', Daniel Ashie Kotey², \\ Dickson Korku Gamedoagbao², Mark Dadoza ${ }^{3}$, Martin Yeboah ${ }^{1}$ and Kwadwo Ofori ${ }^{4}$
}

\begin{abstract}
Background: Participatory plant breeding leads to early adoption of a newly released variety as farmers would be aware of whatever advantage it might have over prior existing ones as early as possible. Cowpea farmers around Ohawu in the Volta Region of Ghana where the crop is one of the most important cash crops had no variety specifically developed for their environment. This research followed farmers' interest identified earlier for the development of varieties with preferred consumer traits.

Methods: Farmers were chosen from 25 communities within the cowpea growing area by the help of agricultural extension officers. Fifty farmers including 25 males and females each, 7 scientists and 15 other persons with different backgrounds were involved in the selection exercise. The final plants selected were based on the total number of participants' endorsement and analysis of variance for their seed size.

Results: Selections were made from six $\mathrm{F}_{3}$ populations with parents of various unique traits obtained from Botswana, Ghana, Nigeria, Senegal, or United States of America. Four most liked cowpea plants from each of the six populations were selected to be advanced and tried in multi-locations towards probable release.

Conclusions: Participants were very enthused with the selection exercise hoping of seeing some of their selections resulting into varieties. Farmers were interested in selecting plants with long multiple pods and early maturing. The exercise was educative for all participants.
\end{abstract}

Keywords: Agricultural extension, Cowpea, Genotypes, Seed coat colour, Seed size, Varieties

\section{Background}

One of the important traits desired in cowpea [Vigna unguiculata (L.) Walp] by consumers is large seed size in West Africa [1-4]. Large seed size preference is not limited to cowpea but known in some other crops such as rice [5]. However, much crop breeding objectives have not been directly focused on seed size compared with such traits as biotic and abiotic stress tolerance [6, 7]. This is not to say that seed size has never been studied. Conflicting reports on the number of genes controlling

\footnotetext{
*Correspondence: kegbadzor@wacci.edu.gh

${ }^{1}$ West Africa Centre for Crop Improvement, University of Ghana, Legon,

Accra, Ghana

Full list of author information is available at the end of the article
}

seed size inheritance in cowpea as well as the gene action (additive or dominance) have been made by different authors indicating the complexity of the genetic control of the trait [1].

Seed coat pigmentation, like size, is also important for consumers of cowpea in Ghana and other parts of the world [2]. Pigmentation of seeds and other parts of the plant is due to the synthesis of anthocyanins and other flavonoids. Flavonoids represent a large class of secondary plant metabolites within which anthocyanins are the most known [8]. These anthocyanins are water-soluble pigments and are found in all tissues in plants throughout the plant kingdom [9]. Anthocyanins are known to be important to plants in response to abiotic factors such as drought [9] as well as biotic (insect pests' resistance) [10]. 
Besides the roles of anthocyanin to the plant, it controls pigmentation of the seed coat which consequently has influence on consumer preference.

Contact with farmers and cowpea dealers revealed that large cream-seeded cowpea are preferred by most consumers in Ghana [1, 2, and 11]. However, the popular Ghanaian cowpea varieties are inferior to imported types in these two traits. Participatory selection of large cream cowpea for varietal development would boost the production and utilization of the crop in Ghana and reduce its importation. Selection with farmers at Ohawu which is a noted cowpea production area will help not only in the timely address of gene environment interaction but also inculcate other traits of interest to farmers in the breeding goal. The objective of this study was to use researcher-farmer participatory approach to select cowpea lines from seven segregating populations toward variety development with focus on seed size and colour as well as agronomic traits of interest to the farmers.

\section{Methods}

\section{Genetic materials}

Seven cowpea genotypes from different sources were chosen for the varietal development. The genotypes are listed in Table 1.

Bambey21 was crossed with Tona, Nhyira, UCR779 and Gbode in a screen house at West Africa Centre for Crop Improvement (WACCI) farm, University of Ghana in September, 2012. CB27 was also crossed with Gh3710 and UCR779. The $\mathrm{F}_{1} \mathrm{~s}$ of all the crosses were advanced to $F_{2}$ at Bunso, in December, 2012. In March, 2013, $F_{2}$ plants were grown at Bunso and selection was made again towards farmer participatory selection at Ohawu (Fig. 1).

\section{Geographic location and identification of farmers}

Fifty cowpea farmers around Ohawu in the Ketu North District of the Volta Region were identified by the help of the Agricultural Extension Officer and his assistants

Table 1 Source and trait of interest of cowpea genotypes selected for varietal development

\begin{tabular}{|c|c|c|}
\hline Genotype & Source & Distinctive trait of interest \\
\hline CB27 & $\begin{array}{l}\text { University of California } \\
\text { riverside }\end{array}$ & Large white seed \\
\hline UCR779 & $\begin{array}{l}\text { University of California } \\
\text { riverside }\end{array}$ & Large seed, aphid resistance \\
\hline Gh3710 & CSIR-PGRRI & Local adapted, early maturing \\
\hline Bambey21 & Senegal, through UCR & White, erect \\
\hline Tona & CSIR-CRI & Local variety \\
\hline Nhyira & CSIR-CRI & Local variety \\
\hline Gbode & Farmer, Ho & Farmer/consumer preferred \\
\hline
\end{tabular}

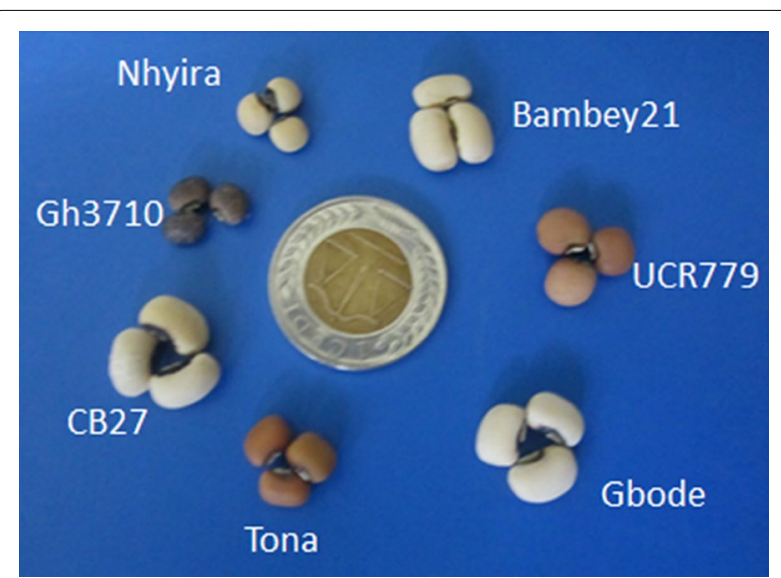

Fig. 1 Seeds of the cowpea genotypes used in hybridization

in the area. Some of the communities covered fell under two other Districts namely Keta Municipal and Akatsi (Fig. 2). The farmers who were drawn from 25 cowpea growing communities between Doveme, Dagbamatey, Xevi and Tadzewu were made up of 25 males and females each. Seven scientists and 15 other persons with different backgrounds were also involved in the selection exercise. Ghana has no official national regulations or guidelines for human subjects' research. Consents of all the participants were obtained towards publication of the results as a research article.

\section{Planting at Ohawu}

Field for planting of the cowpea populations was at Ohawu in the Ketu North District of the Volta Region. The vegetation was cleared in the first week of June followed by ploughing. Planting was done on the 17th of June, 2013 with the spacing of $60 \mathrm{~cm}$ by $80 \mathrm{~cm}$. The field was rain-fed (rainfall figures during the period in Table 2). Hoe weeding which was done in the 3rd and 5th week of planting was followed immediately with insecticide application. The insecticide used was cymethoate and it was applied at $1.5 \mathrm{~L} / \mathrm{ha}$. Harvesting was done as and when different individual plants had dried pods from the various populations from the 15th of August after the participatory selection.

\section{Cowpea lines selection with farmers}

Selections were made from six different populations. Line selection was made from $\mathrm{F}_{3}$ population of $\mathrm{CB} 27 /$ Gh3710. Selection from the other five $F_{3}$ populations, four of which had Bambey 21 as the female parent and the males as, Gbode, Nhyira, Tona and UCR779 were based on single plants. The fifth population was UCR779/CB27. Individual farmers indicated their three best lines (in the 

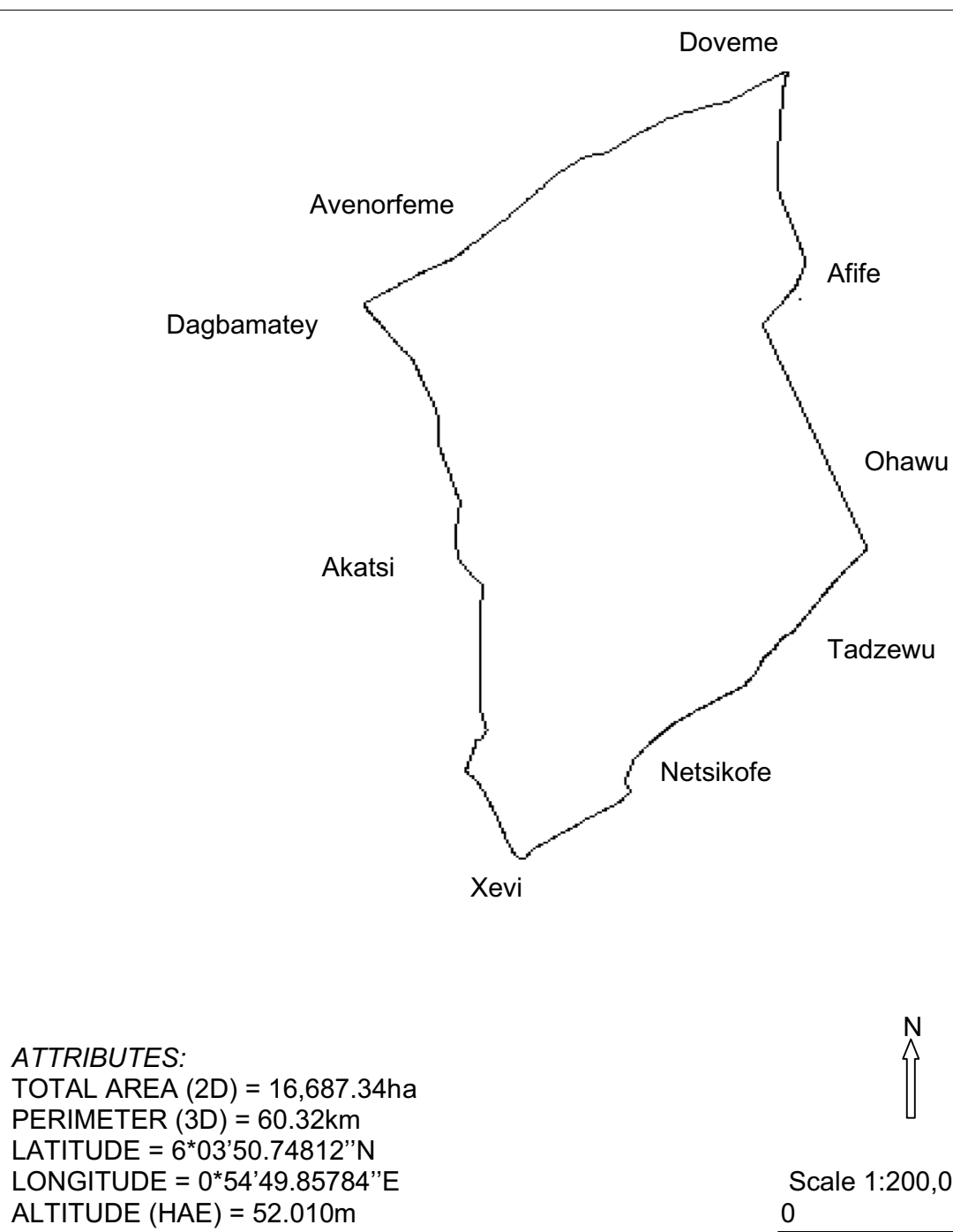

Fig. 2 Map of the cowpea growing areas in the Ketu North and parts of Akatsi District and Keta Municipality

case of CB27/Gh3710) or the three best individual plants (from the five other populations) 58 days after planting, by placing cards under them.

After harvest plants with acceptable seed coat colour were included in the next stage of selection which was based on seed size. One hundred seed weight of the selected lines were measured.

\section{Statistical analysis}

Simple statistic parameters such as means and mode were used. Analysis of variance was performed on 100 seed weight.
Table 2 Rainfall figures at Ohawu (Ketu North District) from June to August 2013

\begin{tabular}{|c|c|c|c|c|c|}
\hline \multicolumn{2}{|c|}{ June } & \multicolumn{2}{|l|}{ July } & \multicolumn{2}{|c|}{ August } \\
\hline Day & Quantity (mm) & Day & Quantity (mm) & Day & Quantity \\
\hline $1 \mathrm{st}$ & 3.6 & 4 th & 30.0 & Nil & \\
\hline 2nd & 3.6 & 15th & 3.6 & & \\
\hline 5 th & 14.4 & 24th & 14.0 & & \\
\hline 9th & 21.6 & & & & \\
\hline 11th & 9.6 & & & & \\
\hline
\end{tabular}

Total quantity of rainfall during the growth period of the cowpeas $=47.6 \mathrm{~mm}$ 


\section{Results}

\section{Participatory field selection}

There were three rounds of selection, each of the first two serving as curling level for the subsequent one. At the first stage, farmers and other participants in the selection indicated their preferred plants based on their own judgment. All plants with at least one farmer's endorsement qualified for the next stage of the selection. The result of the selection is presented in Table 3. The number of plants selected per population varied from the least of 13 for Bambey21/ Tona to the maximum of 26 for Bambey21/UCR779. Some of the plants were selected by a single participant while some were selected by many of them with the highest value of 36 for plant number 5 in the UCR779/CB27 population.

\section{Selection based on seed coat colour}

Any plant selected by at least one person was harvested at seed maturity and included in the next level of selection. Harvesting started 58 days after planting, a period within which some of the plants had dried pods. The second stage of selection was for seed coat colour.
Table 4 shows the number of plants selected per population and the number of them accepted based on the seed coat colour. Many of the selected plants by farmers had similar appearance and could not be developed into different varieties, so, only one was chosen among such plants.

\section{Selection based on seed size}

The number of plants selected for analysis of variance per population is shown in Table 4 in the "number of plants accepted" column. The least number of plants selected was 4 for CB27/Gh3710 whilst the most was 7 for three populations namely, Bambey21/UCR779, Bambey21/Gbode and UCR779/CB27. The numbers selected from Bambey21/Nhyira and Bambey21/Tona were 6 and 5, respectively. Analysis of variance for 100 seed weight was performed on the seeds of accepted plants including the parents as checks for each population and the result is shown in Table 5 . The four heaviest seeds were accepted as the selected plants from each of the populations.

Table 3 Plants selected from various populations by participants

\begin{tabular}{|c|c|c|c|c|c|c|}
\hline \multirow[t]{2}{*}{ Plant no. } & \multicolumn{6}{|c|}{ Percentage of participants who selected a given plant } \\
\hline & CB27/Gh3710 & Bambey21/UCR779 & Bambey21/Gbode & Bambey21/Nhyira & UCR779/CB27 & Bambey21/Tona \\
\hline 1 & 7 & 25 & 3 & 7 & 1 & 38 \\
\hline 2 & 22 & 4 & 21 & 32 & 10 & 24 \\
\hline 3 & 15 & 6 & 17 & 4 & 24 & 1 \\
\hline 4 & 3 & 6 & 10 & 3 & 3 & 3 \\
\hline 5 & 3 & 6 & 1 & 4 & 50 & 14 \\
\hline 6 & 11 & 1 & 19 & 35 & 10 & 1 \\
\hline 7 & 29 & 3 & 21 & 8 & 28 & 14 \\
\hline 8 & 29 & 4 & 13 & 7 & 39 & 44 \\
\hline 9 & 15 & 1 & 7 & 3 & 1 & 1 \\
\hline 10 & 1 & 1 & 10 & 18 & 10 & 21 \\
\hline 11 & 1 & 10 & 14 & 4 & 3 & 6 \\
\hline 12 & 24 & 13 & 1 & 13 & 1 & 14 \\
\hline 13 & 3 & 1 & 13 & 24 & 1 & 24 \\
\hline 14 & 3 & 1 & 42 & 19 & 6 & \\
\hline 15 & 3 & 6 & 11 & 7 & & \\
\hline 16 & 3 & 29 & & & & \\
\hline 17 & 24 & 1 & & & & \\
\hline 18 & 7 & 1 & & & & \\
\hline 19 & 7 & 31 & & & & \\
\hline 20 & 14 & 22 & & & & \\
\hline 21 & & 1 & & & & \\
\hline 22 & & 3 & & & & \\
\hline 23 & & 13 & & & & \\
\hline 24 & & 1 & & & & \\
\hline 25 & & 7 & & & & \\
\hline 26 & & 4 & & & & \\
\hline
\end{tabular}


Table 4 Number of plants accepted per population based on seed coat colour from population

\begin{tabular}{lll}
\hline Population & $\begin{array}{l}\text { Number of field } \\
\text { selected plants }\end{array}$ & $\begin{array}{l}\text { Number of plants } \\
\text { accepted }\end{array}$ \\
\hline CB27/Gh3710 & 20 & 4 \\
Bambey21/UCR779 & 26 & 7 \\
Bambey21/Gbode & 14 & 7 \\
Bambey21/Nhyira & 15 & 6 \\
UCR779/CB27 & 15 & 7 \\
Bambey21/Tona & 13 & 5 \\
\hline
\end{tabular}

\section{Discussion}

At the time of selection (58 days after planting) farmers were mainly interested in yield and early maturity. They, therefore, chose plants with matured pods that were long and multiple per peduncle. Some farmers opened pods to be sure on what the seeds looked like before selecting them, although, they were entreated not to do so. Although some of the farmers were independent and chose what they decided on, some tend to be influenced by friends leading to many of them selecting same plants. Farmers were in general enthused with the selection activities and this will contribute in developing varieties with farmers' desired traits [12].

After harvesting, some of the plants selected were rejected because of having less desirable consumer quality seed coat. Accepted seeds were mainly cream/white seed coated [2, 11]. However, few accepted plants had mottle or brown seed coat colour because of the extreme large number of farmers' endorsement. The plants with unattractive seed coat pigmentation but with high endorsement by farmers may be used in further breeding programmes.

A number of selected plants had similar morphology at the vegetative stage and also same seed features. It would not be possible to develop and release such plants as separate varieties through single seed descent; therefore, the one with highest number of farmer's selection was used to represent them. In so doing the use of bulking is also avoided as it is less effective than the single seed descent [3]. This led to a drastic decrease in the number of plants selected to the number accepted for seed size evaluation.

All of the four plants selected from CB27/Gh3710 had average 100 seed weight significantly higher than that of the smaller seeded parent (Gh3710). The heavier parent, CB27 was heavier than all the selected plants except "Plant number four". However, Plant number four was not significantly heavier than CB27. All of the plants had cream-seeded coat with three having black eye and the forth mottling. The three plants with black eyes were different in the size of the eye as well as the seed weight. All of the selected lines had dry pods before 60 days after planting which are earlier than 65-70 days considered by [13] as early maturing. Early maturity is a very important objective in breeding cowpea and other crops as it is known to be a adaptive feature [14], especially in these times of shortening rainfall periods [15]. In this respect, the selected plants of CB27/Gh3710 are very promising.

Apart from "Plant number 6", all of the selected ones from the population of Bambey21/UCR779 were significantly heavier than both parents. This shows effectiveness of selection for seed size in early generations of cowpea [16]. Effectiveness in selection in early generations for

Table 5 One hundred seed weight $(\mathrm{g})$ of selected plants as compared with their parents

\begin{tabular}{|c|c|c|c|c|c|c|c|c|c|c|c|}
\hline \multicolumn{2}{|c|}{ UCR779/CB27 } & \multicolumn{2}{|c|}{ Bambey21/UCR779 } & \multicolumn{2}{|c|}{ Bambey21/Gbode } & \multicolumn{2}{|c|}{ Bambey21/Tona } & \multicolumn{2}{|c|}{ CB27/Gh3710 } & \multicolumn{2}{|c|}{ Bambey21/Nhyira } \\
\hline Genotype & Weight & Genotype & Weight & Genotype & Weight & Genotype & Weight & Genotype & Weight & Genotype & Weight \\
\hline UCR779 & 19.20 & Bambey21 & 16.46 & Bambey21 & 16.46 & Bambey21 & 16.46 & CB27 & 20.28 & Bambey21 & 16.46 \\
\hline CB27 & 20.28 & UCR779 & 19.20 & Gbode & 17.98 & Tona & 16.7 & Gh3710 & 10.54 & Nhyira & 13.02 \\
\hline Plant $1^{\mathrm{a}}$ & 18.98 & Plant $1^{\mathrm{a}}$ & 22.78 & Plant 1 & 16.76 & Plant 1 & 14.84 & Plant $1^{\mathrm{a}}$ & 14.72 & Plant 1 & 13.48 \\
\hline Plant 2 & 18.84 & Plant $2^{\mathrm{a}}$ & 21.18 & Plant 2 & 17.88 & Plant $2^{\mathrm{a}}$ & 21.82 & Plant $2^{a}$ & 15.48 & Plant $2^{a}$ & 25.08 \\
\hline Plant 3 & 20.46 & Plant 3 & 16.94 & Plant $3^{a}$ & 28.28 & Plant $3^{a}$ & 14.88 & Plant $3^{a}$ & 18.50 & Plant $3^{\mathrm{a}}$ & 15.08 \\
\hline Plant $4^{a}$ & 27.54 & Plant 4 & 18.20 & Plant $4^{a}$ & 22.52 & Plant $4^{a}$ & 18.84 & Plant $4^{a}$ & 20.88 & Plant $4^{a}$ & 17.20 \\
\hline Plant 5 & 21.66 & Plant $5^{a}$ & 25.44 & Plant $5^{a}$ & 20.46 & Plant $5^{a}$ & 16.54 & & & Plant 5 & 14.84 \\
\hline Plant $6^{\mathrm{a}}$ & 22.92 & Plant $6^{\mathrm{a}}$ & 18.38 & Plant 6 & 18.24 & & & & & Plant $6^{a}$ & 17.76 \\
\hline Plant $7^{a}$ & 29.00 & Plant 7 & 16.88 & Plant $7^{a}$ & 18.62 & & & & & & \\
\hline Grand X & 22.10 & & 19.5 & & 19.69 & & 17.15 & & 16.73 & & 16.62 \\
\hline F.pr & $<0.001$ & & $<0.001$ & & $<0.001$ & & $<0.001$ & & $<0.001$ & & $<0.001$ \\
\hline SE & 0.82 & & 0.75 & & 0.62 & & 0.39 & & 0.59 & & 0.49 \\
\hline CV \% & 3.7 & & 3.9 & & 3.1 & & 2.2 & & 3.5 & & 2.9 \\
\hline LSD 5 (\%) & 1.06 & & 0.97 & & 0.8 & & 0.5 & & 0.78 & & 0.63 \\
\hline
\end{tabular}

a Selected plants 
seed size in chickpea has also been reported [17]. Idea from chickpea may be applicable in cowpea as synteny has been reported between cowpea and some of its legume relatives [18]. One of the plants had brown seed coat but was included in the selection because of the high number of farmers that endorsed it during the selection. The brown-seeded plant may not be released with that coat colour as a variety but rather subsequently used in hybridization. The three other plants had cream seeds with one having black eye and two with brown eyes but significantly different in seed sizes.

All the seeds of Bambey21/Gbode selected have cream seed coat with black eye but different shapes and sizes. Among the selected plants of Bambey21/Nhyira and Bambey21/Tona were plants with seeds similar to Bambey21. They, however, had different growth habits. Bambey21/Tona has some plants with seeds not having attractive pigmentation but they were included in the selection for their high yields. High yield is one of the most important traits used by farmers in selection. Seed size and numbers are directly related to yield in cowpea and other crops [19].

Plants of UCR779/CB27 population generally had large parts with heavy seeds. Apart from "plant number 1" all of the selected plants were transgressive segregates for large seeds. Plant number 7 of UCR779/CB27 had 100 seed weight of $29.00 \mathrm{~g}$ which was the largest across all populations from which selections were made. All the other plants selected across the various populations had seed size larger than at least that of the smaller parent. Although, mottling seeds are not high priced, one type was included in the selection and may be used in further improvement programme.

\section{Conclusion}

Crop varieties developed through farmers' participation have higher adoption rate compared with those developed by researchers alone. This was the reason for involving farmers from the cowpea growing communities around Ohawu in the Volta Region of Ghana in selecting cowpea plants toward the development of varieties. Farmers' participation and researchers' knowledge were used to select 24 plants from six different bi-parental populations. These selected plants would be advanced toward varietal development focusing on seed size and colour among other traits. The expected varieties to come out of this breeding programme have a very high chance of being adopted because of the level of commitment shown from the onset by farmers.

\section{Authors' contributions}

KFE: the principal investigator. SKO, EYD, KO and MY: the principal investigator's PhD Thesis research supervisors. They gave technical advice in conducting the experiment. DAK and DKG: they were involved in planning of the selection exercise. They contributed to the writing of the manuscript. MD: the agricultural extension officer of the experiment area (Ohawu). He identified the farmers for the selection exercise and also supervised the cultivation of the cowpea plants. All authors read and approved the final manuscript.

\section{Author details}

${ }^{1}$ West Africa Centre for Crop Improvement, University of Ghana, Legon, Accra, Ghana. ${ }^{2}$ CSIR, Plant Genetic Resources Research Institute, Bunso, E.R. Ghana.

${ }^{3}$ Ministry of Food and Agriculture, Ketu North District, V.R. Ghana. ${ }^{4}$ Crop

Science Department, University of Ghana, Legon, Accra, Ghana. ${ }^{5}$ The Biotech Centre, University of Ghana, Legon, Accra, Ghana.

\section{Acknowledgements}

We thank the Alliance for a Green Revolution in Africa (AGRA) for the financial support for the participatory selection. We also appreciate the support given by the following: Messrs. Kudi Emmanuel, Foli Newton, Jonathan Siamey,

Laryeh Samuel, Addo Ebenezer and Ms. Grace Gyamfua.

\section{Competing interests}

The authors declare that they have no competing interests.

Received: 1 April 2015 Accepted: 6 October 2015

Published online: 01 November 2015

\section{References}

1. Drabo I, Redden R, Smithson JB, Aggarwal VD. Inheritance of seed size in cowpea (Vigna unguiculata (L.) Walp). Euphytica. 1984;33:929-34.

2. Langyintuo AS, Lowenberg-DeBoer J, Faye M, Lambert D, Ibrod G, Moussa B, Kergna A, Kushwaha S, Musa S, Ntoukam G. Cowpea supply and demand in West and Central Africa. Field Crops Res. 2003;82:215-31.

3. Tchiagam NJB, Youmbi E, Njintang NY, Bell JM, Maina NA. Generation means analysis of seed sucrose content in cowpea (Vigna unguiculata L. Walp.). Asian J Agric Sci. 2011;3(6):475-80.

4. Egbadzor KF, Yeboah M, Offei SK, Ofori K, Danquah EY. Farmers' key production constraints and traits desired in cowpea in Ghana. J Agric Ext Rural Dev. 2013. doi:10.5897/jaerd.12.118.

5. Song XJ, Huang W, Shi M, Zhu MZ, Lin HX. A QTL for rice grain width and weight encodes a previously unknown RING-type E3ubiquitin ligase. Nat Genet. 2007. doi:10.1038/ng2014.

6. Hall AE, Singh BB, Ehlers JD. Cowpea breeding. Plant Breed Rev. 1997; 15:215-74.

7. Orawu M, Melis R, Laing M, Derera J. Genetic inheritance of resistance to cowpea aphid-borne mosaic virus in cowpea. Euphytica Int J Plant Breed. 2012. doi:10.1007/s10681-012-0756-3.

8. Holton TA, Cornish E. Genetics and biochemistry of anthocyanin biosynthesis. Plant Cell. 1995;7:1071-83.

9. Chalker-Scott L. Environmental significance of anthocyanins in plant stress responses. Photochem Photobiol. 1999;70(1):1-9.

10. Makoi JHJR, Belane AK, Chimphango SB, Dakora FD. Seed flavonoids and anthocyanins as markers of enhanced plant defence in nodulated cowpea (Vigna unguiculata L. Walp.). Field Crops Res. 2010;118:21-7.

11. Quaye W, Adofo K, Buckman SE, Frempong G, Jongerden J, Ruivenkamp G. A socio-economic assessment of cowpea diversity on the Ghanaian market: implications for breeding. Int J Consum Stud. 2011;35:679-87.

12. Quaye W, Frempong G, Jongerden J, Ruivenkamp G. Exploring possibilities to enhance food sovereignty within the cowpea production-consumption network in Northern Ghana. J Hum Ecol. 2009;8(2):83-92.

13. Ishiyaku MF, Singh BB, Craufurd PQ. Inheritance of time to flowering in cowpea (Vigna unguiculata (L.) Walp.). Euphytica. 2005. doi:10.1007/ s10681-005-2435-0.

14. Singh BB, Ajeigbe HA, Tarawali SA, Fernandez-Rivera S, Abubakar M. Improving the production and utilization of cowpea as food and fodder. Field Crops Res. 2003;84:169-77.

15. Muchero W, Ehlers JD, Close TJ, Roberts PA. Mapping QTL for drought stress-induced premature senescence and maturity in cowpea [Vigna unguiculata (L.) Walp.]. Theor Appl Genet. 2009. doi:10.1007/ s00122-008-0944-7. 
16. Lopes FC, Gomes RLF, Rodrigues F, Filho F. Genetic control of cowpea seed sizes. Scientia Agricola. 2003;60(2):315-8.

17. Upadhyaya HD, Sharma S, Gowda CLL. Major genes with additive effects for seed size in kabuli chickpea (Cicer arietinum L.). J Genet. 2011:90-3.

18. Lucas MR, Huynh BL, Cisse N, Drabo I, Ehlers JD, Roberts PA, Close TJ. Association studies and legume synteny reveal haplotypes determining seed size in Vigna unguiculata. Front Plant Sci. 2013. doi:10.3389/ fpls.2013.00095

19. Monpara BA, Gaikwad SR. Combining high seed number and weight to improve seed yield potential of chickpea in India. Afr Crop Sci J. 2014;22(1):1-7.

Submit your next manuscript to BioMed Central and take full advantage of:

- Convenient online submission

- Thorough peer review

- No space constraints or color figure charges

- Immediate publication on acceptance

- Inclusion in PubMed, CAS, Scopus and Google Scholar

- Research which is freely available for redistribution

Submit your manuscript at

www.biomedcentral.com/submit

() BioMed Central 